\title{
ANALISIS SIKAP PEDULI LINGKUNGAN SISWA MELALUI PROGRAM ADIWIYATA DI SMA NEGERI 1 MEDAN
}

\author{
Fadila Azmi ${ }^{1}$, Elfyetti ${ }^{1}$ \\ 1Jurusan Pendidikan Geografi Fakultas Ilmu Sosial Universitas Negeri Medan \\ Jl. Willem Iskandar Psr V Medan Estate Medan, 20211 Indonesia \\ Email: fadilaazmipohan@yahoo.co.id
}

\begin{abstract}
Abstrak
Penelitian ini bertujuan untuk mengetahui : (1) Bentuk program Adiwiyata di SMA Negeri 1 Medan Kecamatan Medan Polonia. (2) Sikap peduli lingkungan siswa melalui program Adiwiyata di SMA Negeri 1 Medan Kecamatan Medan Polonia. Penelitian ini dilakukan di SMA Negeri 1 Medan Kecamatan Medan Polonia tahun 2017. Populasi dalam penelitian adalah seluruh siswa/i SMA Negeri 1 Medan Kecamatan Medan Polonia yang berjumlah 1.712 siswa. Pengambilan sampel ditentukan dengan menggunakan rumus Slovin, sehingga didapatkan sampel sebanyak 95 siswa. Penentuan sampel dalam penelitian ini dilakukan secara acak (propotional random sampling).Teknik pengumpulan data yang digunakan adalah teknik observasi, teknik komunikasi langsung, teknik studi dokumenter dan teknik komunikasi tidak langsung yaitu angket. Teknik analisis data yang digunakan adalah analisis deskriptif. Hasil penelitian ini menunjukkan bahwa: (1) Bentuk program Adiwiyata di SMA Negeri 1 Medan Kecamatan Medan Polonia meliputi: (a) kebijakan sekolah berbasis lingkungan dilihat dari visi dan misi sekolah, program pengembangan diri yang terdiri dari kegiatan rutin sekolah, kegiatan spontan, keteladanandan dan pengkondisian. (b) Kurikulum sekolah berbasis lingkungan meliputi pengintegrasian dalam mata pelajaran. (c) Kebijakan sekolah berbasis partisipatif dilihat dari kegiatan ekstrakulikuler yaitukegiatan UKS dan KIR. (d) Pengelolaan sarana dan prasarana pendukung sekolah. (2) Sikap peduli lingkungan siswa melalui program Adiwiyata di SMA Negeri 1 Medan Kecamatan Medan Polonia cukup tinggi, sebagian besar siswa (77,90\%) tergolong dalam kategori baik dengan rentang nilai 48 - 57 yang terdapat di kelas X, XI dan XII, kategori cukup $(16,80 \%)$ dengan rentang nilai 34 - 47 yang terdapat di kelas X dan XII dan sebagian kecil siswa (5,30\%) tergolong dalam kategori kurang dengan rentang nilai $<33$ terdapat yang terdapat di kelas X. Artinya lebih banyak yang peduli lingkungan di SMA Negeri 1 Medan.
\end{abstract}

Kata Kunci : Sikap Peduli Lingkungan; Adiwiyata

\section{PENDAHULUAN}

Isu tentang lingkungan hidup merupakan salah satu perhatian utama dunia internasional saat ini. Hal ini dipicu oleh perilaku manusia yang kurang peduli pada lingkungannya yang menyebabkan kondisi lingkungan alam semakin hari semakin memprihatinkan. Tidak hanya itu, kualitas lingkungan hidup sekarang ini semakin menurun karena tindakan eksploitatif terhadap alam yang berlebihan tanpa memperhatikan daya dukung lingkungan dan fungsi ekologinya. Perilaku peduli lingkungan merupakan hal yang harus ditanamkan secara terus menerus melalui pembiasaan. Aspek-aspek peduli lingkungan yang di kembangkan di sekolah meliputi pembiasaan memelihara kebersihan dan kelestarian lingkungan sekolah, penyediaan tempat pembuangan sampah, melakukan pembiasaan memisahkan jenis sampah organik dan anorganik, penyediaan peralatan kebersihan, serta pembuatan program cinta bersih lingkungan.

Kementerian Lingkungan Hidup mengeluarkan keputusan No. 5 Tahun 
2013 tentang program pendidikan lingkungan hidup pada jenjang pendidikan dasar dan menengah melalui program Adiwiyata. Program Adiwiyata adalah salah satu program Kementerian Negara Lingkungan Hidup dalam rangka mendorong terciptanya pengetahuan dan kesadaran warga sekolah sehingga menjadi sebuah karakter peduli lingkungan dalam upaya pelestarian lingkungan hidup.

Adapun tujuan diadakannya program Adiwiyata adalah mewujudkan warga sekolah, khususnya peserta didik yang peduli dan berbudaya lingkungan. Program Adiwiyata tingkat sekolah merupakan tempat yang baik dan ideal dimana dapat diperoleh segala ilmu pengetahuan dan berbagai norma serta etika yang dapat menjadi dasar manusia menuju terciptanya kesejahteraan hidup dan menuju kepada cita-cita pembangunan berkelanjutan.

SMA Negeri 1 Medan merupakan salah satu sekolah yang terletak di Jalan Cik Ditiro, Kelurahan Madras Hulu, Kecamatan Medan Polonia. Sekolah ini memiliki jumlah siswa 1.712 orang siswa dengan jumlah guru sebanyak 104 orang tahun pelajaran 2016/2017, jumlah petugas kebersihan sekolah sebanyak 26 orang serta terdapat jumlah kelas 44 ruangan. SMA Negeri 1 Medan juga pernah mendapatkan penghargaan Green House atau sekolah hijau serta penghargaan Adiwiyata pada tahun 2015.

$$
\text { Berdasarkan hasil studi }
$$

pendahuluan yang dilakukan oleh peneliti pada tanggal 20 Desember 2016 di SMA Negeri 1 Medan diketahui bahwa SMA Negeri 1 Medan merupakan salah satu sekolah menengah atas yang sedang merintis serta mengembangkan kerakter sekolah yang peduli dan berbudaya lingkungan sebagai wujud implementasi peduli lingkungan melalui kebijakan sekolah yang meliputi visi dan misi sekolah, kegiatan lingkungan berpartisipatif, pengelolaan dan penyediaan sarana prasarana pendukung dan pengembangan diri. merupakan program yang ada di sekolah terkait kegiatan Sabtu bersih, UKS (Usaha Kegiatan Siswa) dan KIR (Karya Ilmiah Remaja). Dengan demikian dapat peneliti lihat bahwa adanya pelaksanaan program Adiwiyata terkait dengan sikap peduli lingkungan di SMA Negeri 1 Medan. Hal ini dapat diketahui dari visi dan misi tersebut yaitu "Beriman, Bertaqwa, dan Unggul dalam Prestasi serta berwawasan lingkungan". Adapun misinya yaitu "melaksanakan pembelajaran aktif, kreatif, dan menyenangkan untuk menghantarkan siswa agar berprestasi dalam IPTEK, olahraga dan seni berlandaskan Imtaq dan siap bersaing di Era Globalisasi serta peduli terhadap lingkungan sekolah".

Walaupun telah mendapat penghargaan Adiwiyata sekolah, dari hasil wawancara yang dilakukan peneliti dengan ibu Yulidar selaku bidang sarana dan prasarana sekaligus sebagai Koordinator pelaksana program Adiwiyata menyatakan bahwasanya kepedulian siswa terhadap lingkungan sekolah masih kurang. Hal ini dapat dilihat dari masih banyak ditemukan siswa yang mencoret-coret meja, kursi, dinding-dinding sekolah dengan menggunakan bolpoin, membuang sampah sembarangan, tidak melaksanakan tugas piket kelas, sering ditemukannya sampah didalam laci meja, serta pada sebagian besar ruangan kelas terlihat sampah yang berserakan. Padahal tong sampah yang disediakan pihak sekolah untuk tempat pembuangan sampah (TPS) organik dan anorganik berjumlah 60 tong sampah, sedangkan untuk tempat pembuangan akhir (TPS) organik dan anorganik berjumlah 2 unit, pihak sekolah juga menyediakan 30 toilet untuk siswa. Pihak kebersihan sekolah juga sering menemukan kran air yang tidak dimatikan setelah digunakan. Masalah-masalah lingkungan lingkungan yang muncul, kalau dikaji secara seksama merupakan satu bentuk akibat dari 
perilaku manusia itu sendiri, termasuk pola pikir, sikap serta tindakan yang tidak bertanggung jawab terhadap keberadaan lingkungan.

Kondisi sebagaimana diuraikan diatas, membuktikan bahwa adanya permasalahan dengan sikap peduli lingkungan sekolah. Berdasarkan latar belakang masalah tersebut, maka masalah ini perlu diteliti mengenai Sikap Peduli Lingkungan Siswa melalui program Adiwiyata di SMA Negeri 1 Medan Kecamatan Medan Polonia".

\section{METODE PENELITIAN}

Penelitian ini dilakukan di SMA Negeri 1 Medan terletak di Jalan Teuku Cik Ditiro No. 1, Kelurahan Madras Hulu, Kecamatan Medan Polonia, Provinsi Sumatera Utara. Populasi dalam penelitian ini adalah seluruh siswa SMA Negeri 1 Medan yang tersebar di 44 ruang kelas dengan jumlah sebanyak 1.712 orang siswa. sampel yang diambil dalam penelitian ini adalah sebanyak 95 orang. Pemilihan sampel dilakukan dengan metode propotional random sampling. Variabel dalam penelitian ini adalah program Adiwiyata dan sikap peduli lingkungan siswa di SMA Negeri 1 Medan. Teknik pengumpulan data yang digunakan dalam penelitian ini yaitu: observasi, wawancara, dokumentasi dan angket. Adapun teknik analisis data yang digunakan adalah teknik analisis deskriptif yaitu teknik yang dilakukan untuk mendeskripsikan atau menggambarkan keadaan dan fakta objek atau subjek secara sistematis melalui katakata.

\section{HASIL PENELITIAN}

\section{Bentuk Program Adiwiyata di SMA Negeri 1 Medan Kecamatan Medan Polonia.}

Berdasarkan hasil observasi dan wawancara serta didukung dengan hasil dokumentasi yang berkaitan menunjukkan adanya bentuk program Adiwiyata di SMA Negeri 1 Medan
Kecamatan Medan Polonia. Adanya bentuk program Adiwiyata tersebut yaitu kebijakan sekolah yang meliputi:

\section{a. Kebijakan Sekolah Berbasis Lingkungan}

Kebijakan sekolah berbasis lingkungan yang meliputi visi dan misi SMA Negeri 1 Medan. Berdasarkan hasil wawancara dengan koordinator Adiwiyata SMA Negeri 1 Medan yaitu ibu Yulidar, diketahui bahwa salah satu visi SMA Negeri 1 Medan adalah berwawasan lingkungan hidup. Hasil wawancara kepada siswa/i SMA Negeri 1 Medan terkait dengan visi dan misi sekolah menyatakan bahwa mereka mengetahui adanya pemajangan visi dan misi sekolah, namun tidak semua mengetahui tentang isi dari visi dan misi sekolah tersebut. Hal ini dapat dilihat dari 95 responden bahwa sebagian besar siswa (67\%) mengetahui isi dari visi dan misi sekolah tentang peduli lingkungan dan hanya sebagian kecil siswa $(33 \%)$ yang tidak mengetahui isi dari visi dan misi sekolah tentang peduli lingkungan.

Bentuk kegiatan rutin yang dilakukan sekolah dalam sikap peduli lingkungan yaitu kegiatan piket kelas dan Sabtu bersih. Hasil wawancara yang dilakukan kepada siswa/i SMA Negeri 1 Medan diketahui bahwa dari 95 responden sebagian besar siswa (76\%) melakukan kegiatan rutin sekolah yaitu piket kelas dan sabtu bersih dan sebagian kecil siswa $(6 \%)$ yang hanya melakukan kegiatan Sabtu bersih.

Sebagaimana hasil wawancara yang dilakukan peneliti kepada 95 siswa/i SMA Negeri 1 Medan yang menyatakan bahwa hal spontan yang dilakukan oleh guru ketika ada siswa yang berperilaku kurang baik terhadap fasilitas atau lingkungan sekolah adalah dengan dimarahi, dinasehati, dan ditegur.

Dari hasil wawancara dilakukan kepada siswa/i SMA Negeri 1 Medan diketahui bahwa dari 95 responden sebagian besar siswa (57\%) mengatakan bahwa bentuk keteladanan yang 
dicontohkan guru kepada siswa/i SMA Negeri 1 Medan yaitu berpakaian rapi dan ikut kegiatan gotong royong dan sebagian kecil siswa (16\%) yang mengatakan bahwa bentuk keteladanan yang dicontohkan guru kepada siswa/i SMA Negeri 1 Medan yaitu berpakaian rapi.

Dari hasil wawancara yang dilakukan peneliti kepada 95 siswa/i SMA Negeri 1 Medan bahwa semua siswa (95 responden) menyatakan peralatan kebersihan dan bak sampah sudah diletakkan ditempat strategis dan terkondisikan sesuai tempatnya.

\section{b. Kurikulum Sekolah Berbasis Lingkungan \\ Dari hasil wawancara yang} dilakukan kepada siswa/i SMA Negeri 1 Medan diketahui bahwa dari 95 responden mata pelajaran yang terintegrasi dengan lingkungan paling banyak siswa mengatakan pada mata pelajaran Geografi (44\%) dan yang paling sedikit siswa mengatakan pada mata pelajaran Bahasa Indonesia (12\%).

Tidak terlepas dari itu, guru juga menggunakan media pembelajaran dari alam sekitar. Dari hasil wawancara yang dilakukan kepada siswa/i SMA Negeri 1 Medan diketahui bahwa hampir semua siswa $(80 \%)$ pernah menggunakan media pembelajaran dari alam dan hanya sebagian kecil siswa (20\%) yang tidak pernah menggunakan media pembelajaran dari alam. Sekolah juga melaksanakan kegiatan lomba kebersihan kelas setiap 17 Agustus dan hasil wawancara juga diketahui bahwa semua siswa/i SMA Negeri 1 Medan (100\%) pernah mengikuti kegiatan lomba kebersihan kelas.

\section{c. Kegiatan Sekolah Berbasis Partisipatif}

Kegiatan pembiasaan berbasis partisipatif yang mereka lakukan yaitu UKS (Usaha Kegiatan Siswa) dan KIR (Karya Ilmiah Remaja). Adapun siswa/i SMA Negeri 1 Medan yang mengikuti kegiatan UKS dan KIR sebanyak $82 \%$ dan yang tidak mengikuti kegiatan UKS dan KIR yaitu sebanyak $18 \%$.

UKS (Usaha Kegiatan Siswa) merupakan kegiatan yang pada dasarnya ikut bekerja sama dengan KIR (Karya Ilmiah Remaja) membantu dalam pembuatan biopori, pembibitan dan kegiatan pemeliharaan taman. KIR (Karya Ilmiah Remaja)

KIR (Karya Ilmiah Remaja) merupakan kegiatan sekolah yang dilakukan demi tercapainya sikap peduli lingkungan siswa dan pada kegiatan ini diikutsertakan seluruh siswa/i SMA Negeri 1 Medan agar dapat membantu suatu rancangan kegiatan seperti membuat daur ulang sampah dan pembuatan pupuk.

\section{d. Pengelolaan Sarana dan Prasarana Pendukung Sekolah}

Berdasarkan hasil observasi di lingkungan sekolah pada hari Sabtu, 4 Februari 2017, peneliti mendapati bahwa SMA Negeri 1 Medan menyediakan berbagai sarana pendukung dalam sikap peduli lingkungan siswa. Beberapa sarana pendukung yang dimaksud antara lain penyediaan tempat sampah diberbagai tempat dalam kondisi sudah bersih dari sampah setiap pagi hari, penyediaan wastafel diberbagai tempat dalam kondisi yang cukup bersih, penyediaan toilet dan air bersih, penyediaan peralatan kebersihan dan perawatan lingkungan, taman-taman sekolah, wastafel serta slogan-slogan atau poster peduli lingkungan diberbagai sudut sekolah.

Dari hasil wawancara yang dilakukan kepada siswa/i SMA Negeri 1 Medan diketahui bahwa dari 95 responden yang menyatakan penyediaan ruang dan fasilitas sekolah untuk mendukung program Adiwiyata di SMA Negeri 1 Medan sudah baik, karena semua responden menyatakan bahwa ruang dan fasilitas sudah tersedia sangat baik, untuk kebersihan kamar mandi sebagian besar siswa (77\%) mengatakan baik dan hanya $23 \%$ yang mengatakan 


\section{ge}

kurang baik serta untuk pemeliharaan ruang dan bangunan sekolah juga sebagian besar siswa (85\%) mengatakan sudah baik dan hanya $15 \%$ yang mengatakan kurang baik.

2. Sikap Peduli Lingkungan Siswa Melalui Program Adiwiyata Di SMA Negeri 1 Medan Kecamatan Medan Polonia

Berikut adalah uraian mengenai sikap peduli lingkungan siswa melalui program Adiwiyata di SMA Negeri 1 Medan meliputi:

a. Kegiatan Kebersihan Sekolah

Dari hasil wawancara yang dilakukan kepada siswa/i SMA Negeri 1 Medan diketahui bahwa dari 95 responden kegiatan yang dilakukan siswa/i SMA Negeri 1 Medan dalam kegiatan kebersihan sekolah yang paling selalu $(76 \%)$ dilakukan siswa adalah mengikuti kegiatan kebersihan lingkungan sekolah dan yang paling sedikit kegiatan dilakukan siswa yaitu membersihkan kelas sebelum memulai pelajaran (64\%).

b. Pemanfaatan Wastafel

Dari hasil angket siswa diketahui bahwa semua siswa (95 responden) tersebut menjawab selalu mencuci tangan setelah mengutip sampah. Pada umumnya siswa sudah menunjukkan kebiasaan memanfaat-kan wastafel dan kran air untuk mencuci tangan meski terkadang masih melakukan dengan cara yang kurang sesuai.

c. Pemanfaatan Toilet

Pada umumnya dalam pemanfaatan toilet sudah cukup baik. Hal ini juga didukung oleh hasil angket siswa bahwa dari 95 responden ada $82 \%$ yang menyatakan selalu menyiram toilet setelah digunakan.

d. Hemat Energi

Dari hasil angket siswa bahwa dari 95 responden ada $73 \%$ siswa selalu mematikan lampu setelah usai pembelajaran. Hal ini dilakukan sesuai dengan jadwal piket masing-masing.
Hasil pengukuran sikap peduli lingkungan melalui program Adiwiyata di SMA Negeri 1 Medan menunjukkan bahwa siswa/i di SMA Negeri 1 Medan memiliki peduli lingkungan yang tinggi. Dimana nilai tertinggi adalah rentang nilai 48 - 57 terdapat 74 siswa termasuk dalam kategori baik dengan hasil $77,9 \%$, untuk rentang nilai 34 - 47 terdapat 16 siswa termasuk dalam kategori cukup dengan hasil 16,8\% dan nilai terendah adalah rentang nilai < 33 terdapat 5 siswa termasuk dalam kategori kurang dengan hasil 5,3\%.

\section{PEMBAHASAN}

1. Bentuk Program Adiwiyata di SMA Negeri 1 Medan Kecamatan Medan Polonia

a. Kebijakan Sekolah Berbasis Lingkungan

1) Visi dan Misi Sekolah

Berdasarkan hasil wawancara dengan koordinator Adiwiyata SMA Negeri 1 Medan yaitu ibu Yulidar, diketahui bahwa visi SMA Negeri 1 Medan salah satunya yaitu berwawasan lingkungan hidup". Program Adiwiyata berkaitan dengan visi dan misi sekolah sudah sesuai dengan Peraturan Menteri Lingkungan Hidup Nomor 5 Tahun 2011 yang berisi penerapan program sekolah Adiwiyata diaplikasikan di dalam ruang lingkup sekolah berupa adanya visi, misi sekolah yang memuat upaya perlindungan dan pengelolaan lingkungan hidup.

2) Program Pengembangan Diri

a) Kegiatan Rutin Sekolah

Kegiatan rutin yang dilaksanakan di SMA Negeri 1 Medan yaitu piket kelas setiap pagi. Kegiatan tersebut meliputi kegiatan menyapu, merapikan kelas, merapikan rak buku, membuang sampah, merapikan alat-alat belajar. Hal ini sesuai dengan Kementerian Pendidikan Nasional (2011) bahwa kegiatan rutin sekolah merupakan kegiatan yang dilakukan peserta didik secara terusmenerus dan konsisten setiap saat. 
Kegiatan Sabtu bersih juga menjadi kegiatan rutin sekolah di SMA Negeri 1 Medan. Kegiatan Sabtu bersih dilaksanakan oleh seluruh warga sekolah. Kegiatan Sabtu Bersih ini dilaksanakan secara konsisten setiap hari Sabtu di SMA Negeri 1 Medan.

b) Kegiatan Spontan

Kegiatan spontan yang dilakukan kepala sekolah dan guru adalah dengan memberi teguran, peringatan, dan pengertian kepada siswa yang melakukan tindakan kurang baik terhadap lingkungan maupun fasilitas sekolah. Kegiatan spontan tersebut sesuai dengan Kementerian Pendidikan Nasional (2011) yang menyebutkan bahwa kegiatan spontan yaitu kegiatan yang dilakukan secara spontan pada saat itu juga.

a) Keteladanan

Kepala sekolah dan guru sebagai tenaga pendidik senantiasa memberikan contoh dan menjadi teladan bagi peserta didik. Bentuk keteladanan yang diberikan kepala sekolah dan guru kepada siswa dalam pelaksanaan sikap peduli lingkungan siswa yaitu dengan memberi contoh berpakaian rapi, ikut serta dalam kegiatan bersih-bersih bersama dengan anak-anak dan menanam tanaman. Kegiatan yang dilakukan tersebut sesuai dengan Kementerian Pendidikan Nasional (2011) yang menyebutkan bahwa keteladanan adalah perilaku dan sikap kepala sekolah, guru dan tenaga pendidik dalam memberikan contoh yang baik pada peserta didik.

d) Pengkondisian

Pengkondisian yang dilaku-kan

sekolah dalam mendukung pelaksanaan sikap peduli lingkungan siswa melalui program Adiwiyata SMA Negeri 1 Medan yaitu dengan menyediakan fasilitasfasilitas kebersihan, mengadakan kegiatan yang berhubungan dengan lingkungan, menempatkan tempat sampah di setiap kelas serta menanam tanaman yang bermanfaat. Kegiatan yang dilakukan tersebut sesuai dengan Kementerian Pendidikan Nasional (2011) yang menyebutkan bahwa untuk mendukung keterlaksanaan program Adiwiyata sekolah perlu dilakukan pengkondisian lingkungan sekolah.

\section{a. Kurikulum Sekolah Berbasis Lingkungan \\ - Pengintegrasian Dalam Mata Pelajaran}

Berdasarkan RPP (Rencana

Pelaksanaan Pembelajaran) guru mencantumkan nilai-nilai yang akan dicapai dalam proses pembelajaran. Gurumerancang proses pembelajaran yang akan dilaksanakan selama proses pembelajaran. Penggunaan media dan metode dicantumkan dalam RPP yang digunakan selama proses pembelajaran. Sebagaimana Kementrian Pendidikan Nasional (2011) mengemukakan upaya penanaman sikap peduli lingkungan dapat diaplikasikan melalui kurikulum sekolah dan proses pembelajaran.

\section{b. Kebijakan Sekolah Berbasis Partisipatif}

Pelaksanaan kegiatan SMA Negeri 1 Medan adalah UKS (Usaha kegiatan Siswa), dan KIR (Karya Ilmiah Remaja). Hal tersebut sesuai dengan Kementerian Pendidikan Nasional (2011) yang menyebutkan bahwa pengembangan PLH dapat dilakukan dengan kegiatan berbasis partisipatif yang meliputi penciptaan kegiatan ekstrakulikuler atau kurikuler yang mendukung program Adiwiyata sekolah.

\section{c. Pengelolaan Sarana dan Prasarana Pendukung Sekolah}

Hasil penelitian ini dapat dilihat dari pengelolaan sarana dan prasarana pendukung sekolah SMA Negeri 1 Medan. Beberapa sarana pendukung yang dimaksud antara lain penyediaan tempat sampah diberbagai tempat dalam kondisi sudah bersih dari sampah setiap pagi hari, penyediaan wastafel diberbagai tempat dalam kondisi yang cukup bersih, penyediaan toilet dan air bersih, penyediaan peralatan kebersihan dan perawatan lingkungan, taman-taman sekolah, tempat sampah yang disediakan 


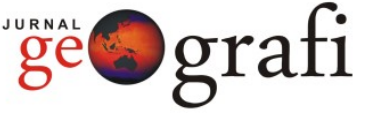

sekolah, yaitu tempat sampah organik dan anorganik. Sekolah juga menyediakan toilet dan air bersih. Keberdaan 5 toilet untuk berbagai tempat, mulai dari toilet untuk guru, kelas X, XI, XII dan dibagian mesjid. Setiap toilet dilengkapi dengan bak penampung air bersih. Ada juga himbauan untuk menyiram WC setelah memakai melalui tulisan yang sengaja ditempelkan dipintu salah satu toilet.

2. Sikap Peduli Lingkungan Siswa Melalui Program Adiwiyata Di SMA Negeri 1 Medan Kecamatan Medan Polonia

Pada kegiatan siswa melalui program Adiwiyata di SMA Negeri 1 Medan meliputi: Kegiatan kebersihan sekolah, pemanfaatan wastafel, pemanfaatan toilet dan hemat Energi. Dari keseluruhan kegiatan tersebut sudah sesuai dengan teori yang dikemukakan oleh Kurniawan (2013) terkait dengan indikator keberhasilan sekolah dan kelas dalam pengembangan sikap peduli lingkungan siswa.

Pada hasil olahan data primer untuk sikap peduli lingkungan siswa melalui program Adiwiyata di SMA Negeri 1 Medan dengan hasil nilai tertinggi adalah rentang nilai 48 - 57 terdapat 74 siswa termasuk dalam kategori baik dengan hasil 77,9\%, untuk rentang nilai 34 - 47 terdapat 16 siswa termasuk dalam kategori cukup dengan hasil 16,8\% dan nilai terendah adalah rentang nilai < 33 terdapat 5 siswa termasuk dalam kategori kurang dengan hasil 5,3\%. Artinya lebih banyak siswa yang peduli lingkungan di SMA Negeri 1 Medan.

\section{KESIMPULAN DAN SARAN}

Berdasarkan pembahasan, maka diperoleh kesimpulan sebagai berikut:

1. Bentuk program Adiwiyata di SMA Negeri 1 Medan Kecamatan Medan Polonia yaitu: (a) Kebijakan sekolah berbasis lingkungan dilihat dari visi dan misi sekolah, program pengembangan diri yang terdiri dari kegiatan rutin sekolah, kegiatan spontan, keteladanandan dan pengkondisian. (b) Kurikulum sekolah berbasis lingkungan meliputi pengintegrasian dalam mata pelajaran. (c) Kebijakan sekolah berbasis partisipatif dilihat dari kegiatan ekstrakulikuler yaitu Usaha Kegiatan Siswa (UKS) dan Karya Ilmiah Remaja (KIR). (d) Pengelolaan sarana dan prasarana pendukung sekolah.

2. Sikap peduli lingkungan siswa melalui program Adiwiyata di SMA Negeri 1 Medan Kecamatan Medan Polonia cukup tinggi, sebagian besar siswa $(77,90 \%)$ tergolong dalam kategori baik dengan rentang nilai 48 - 57 yang terdapat di kelas X, XI dan XII, kategori cukup $(16,80 \%)$ dengan rentang nilai $34-47$ yang terdapat di kelas X dan XII dan sebagian kecil siswa $(5,30 \%)$ tergolong dalam kategori kurang dengan rentang nilai $<33$ terdapat yang terdapat di kelas $X$. Artinya lebih banyak siswa/i SMA Negeri 1 Medan yang peduli lingkungan.

Berdasarkan kesimpulan, dapat diambil saran sebagai berikut:

1. Pelaksanaan program Adiwiyata sudah dilaksanakan, namun diharapkan bagi dinas pendidikan untuk lebih menggalakkan lagi program Adiwiyata untuk meningkatkan sikap peduli lingkungan pada siswa.

2. Pelaksanaan program Adiwiyata di SMA Negeri 1 Medan sudah dilaksanakan, namun masih ada siswa yang membuang sembarangan. Hal itu disarankan kepada kepala sekolah untuk meningkatkan sikap peduli lingkungan pada siswa.

3. Pelaksanaan program Adiwiyata di SMA Negeri 1 Medan sudah dilaksanakan, namun sebaiknya bagi guru supaya menyampaikan materi geografi yang relevan dengan 
4. lingkungan hidup disertai penanaman sikap peduli lingkungan sehingga siswa dapat meningkatkan sikap peduli lingkungan sekolah sesuai dengan yang diharapkan.

5. Pelaksanaan program Adiwiyata di SMA Negeri 1 Medan sudah dilaksanakan, namun masih ada siswa yang membuang sembarangan. Oleh karena itu, disarankan kepada siswa agar lebih meningkatkansikap peduli lingkungan sehingga lingkungan sekolah maupun kelas lebih besih.

\section{DAFTAR PUSTAKA}

Al-anwari, Amirul Mukminin. 2014. Strategi Pembentukan Karakter Peduli Lingkungan di Sekolah Adiwiyata Mandiri. Jurnal. Jambi: IAIN Sulthan Thahah Saifuddin Jambi

Anonim. 2009. UU RI No. 32 Tahun 2009 tentang Perlindungan dan Pengelolaan Lingkungan Hidup. Jurnal. Jakarta : Citra Umbara

Artamadya, Fatmadhona. 2015. Analisis Implementasi Sikap Peduli Lingkungan dalam Meningkatkan Kualitas Lingkungan Sekolah pada SMA Negeri 1 Sunggal Kecamatan Sunggal Kabupaten Deli Serdang. Skripsi. Medan: Universitas Negeri Medan

Damanik, M. R. S., \& Nurman, A. (2016). PEMANFAATAN BLOG PADA MATA KULIAH SISTEM INFORMASI GEOGRAFI JURUSAN PENDIDIKAN GEOGRAFI FAKULTAS ILMU SOSIAL UNIVERSITAS NEGERI MEDAN. IURNAL GEOGRAFI, 8(1).

Gunawan, Zaini. 2016. Pengembangan Program Adiwiyata dalam Mewujudkan Sekolah Peduli dan Berbudaya Lingkungan. Jurnal. Probolinggo

Isa, Muhammad. 2016 "Organisasi Siswa Intra Sekolah (OSIS)”, (Online),
(https://www.Academia.Edu/477

0030/Organisasi Siswa Intra Sekolah), diakses 12 Februari 2017 pukul 22.24 WIB

Julismin, J. (2017). ALAM, SUMBER BELAJAR YANG TIDAK PERNAH HABIS. ЛURNAL GEOGRAFI, 1(1), 77-83.

Kemendiknas. 2010. Pengembangan Pendidikan Budaya dan Karakter Bangsa. Jakarta

Kemendiknas. 2011. Panduan Pelaksanaan Pendidikan Karakter. Jakarta: Badan Penelitian dan Pengembangan Pusat Kurikulum dan Perbukuan

Kementerian Lingkungan Hidup dan Kementerian Pendidikan dan Kebudayaan. 2011. Panduan Adiwiyata Sekolah Peduli dan Berbudaya Lingkungan. E-Book. Diakses dari http://www.menlh.go.id/informa si-mengenai-adiwiyata/ pada tanggal 2 Februari 2017, jam 20.15 WIB

Menteri Lingkungan Hidup. Permendiknas Lingkungan Hidup No. 07 Tahun 2011 tentang Program Adipura

Pati. 2014. Fasilitas Pembelajaran. (Online: ht tp:// sisipandanglain.co.id/2014/1 1 fasilitas-pembelajarandalam.html/diakses 22 Desember 2016 pukul 06.56 WIB)

Puri, Engli Ratna. 2016. Analisis Implementasi Kepedulian Lingkungan Melalui kegiatan OSIM Menuju Sekolah Adiwiyata Di MAN Lima Puluh T.A 2015/2016. Skripsi. Medan: Universitas Negeri Medan

Rika, Kartika. 2011. Kontribusi Hasil Pembelajaran geografi terhadap Perilaku Siswa Peduli Lingkungan (Studi Deskriptif Kelas XII IPS di SMA negeri 2 Kota Sukabumi. Skripsi. Bandung: Universitas Pendidikan Indonesia

UU No. 20 Tahun 2003 Tentang Sistem Pendidikan Nasional 